\title{
Risk factors for tuberculosis
}

\author{
P.D.O. Davies
}

ABSTRACT: Risk factors for tuberculosis. P.D.O. Davies.

The risk of developing tuberculosis is dependent on both the risk of being infected and the risk of infection leading on to active disease. The former will depend on the incidence of tuberculosis in the community where the individual lives or works. The latter will depend on many factors impinging on the individual both genetic and environmental.
The greatest single risk factor for developing tuberculosis from infection is concurrent HIV infection. Where these two infections are prevalent tuberculosis case rates have risen dramatically and will continue to do so unless either infection can be curtailed.

Monaldi Arch Chest Dis 2005; 63: 1, 37-46.

Keywords: Risk factor, tuberculosis, HIV, Aids, Genetic, Environment.

Tuberculosis Research Unit, Cardiothoracic Centre, Liverpool, UK.

Correspondence: Peter D O Davies DM FRCP, Director Tuberculosis Research Unit, Cardiothoracic Centre, Liverpool L14 3PEUK; e-mail: Peter.Davies@ctc.nhs.uk

\section{Introduction}

There are two distinct aspects to the risk of developing tuberculosis: the risk of becoming infected and the risk that the infection may go on to develop into disease. The risk of becoming infected will depend on the prevalence of tuberculosis in the community in which an individual is living. The risk of infection developing into disease is multifactorial but the healthy adult with no risk factors in terms of life-style and absence of medical risk factors probably runs less than a 5\% chance of progressing from infection alone to disease. On the other hand the unfortunate individual who acquires HIV infection in an area where tuberculosis is rife, such as sub-Saharan Africa will run a greater than $30 \%$ chance of developing tuberculosis.

This paper is not intended as an exhaustive review of all the literature on the subject but aims to pick out the most important studies, which may not be the most recent, leading to firm conclusions on risk factors for tuberculosis.

\section{Definitions}

Tuberculosis infection, now termed Latent Tuberculosis Infection (LTBI), is characterised by the presence of bacilli within a host individual but with no evidence of symptoms or pathology [1]. The only evidence may be a positive tuberculin skin test or a positive QuantiFERON or ELISA blood test [2]. The presence of disease is characterised by symptoms due to tuberculosis with evidence of pathological changes, which may be anywhere in the body but usually the lungs. The diagnosis of tuberculosis may be suspected by the presence of symptoms and pathology but can only be confirmed by isolating, that is growing, the responsible bacillus: M. tuberculosis complex, from a specimen taken from the patient [3].

\section{The current world problem}

In fact about one third of the world's population is infected with the tubercle bacillus, 2 billion people, and each year eight million develop the disease of whom about 1.8 million die. Due to a combination of population growth and HIV/AIDS, the single biggest risk factor for infection leading on to disease, this number is increasing steadily by between 1.5 and $2 \%$ each year [4].

\section{Historical aspects}

Archaeological data show that tuberculosis has afflicted man for at least eight thousand years [5]. The disease was present in society in varying incidence but did not appear to be a major killer of the human race until the early nineteenth century. Evidence from England suggests that with the advent of the industrial revolution, in the late $18^{\text {th }}$ and early $19^{\text {th }}$ centuries, tuberculosis became a major epidemic killing roughly one in four of the urban population $[6,7]$. The reason was chiefly horrendously poor housing coupled with a high density of population, so that the working population could easily walk to the factories. This, together with poor nutrition, resulted in a rapid spread of tuberculosis with widespread morbidity and mortality.

This may have represented the origin of the modern pandemic of tuberculosis. The high rates of tuberculosis present in Western Europe around the early 1800 s were probably spread gradually to the rest of the world [8].

This resulted in a peaking of rates in North America in the 1880s, in African and Asia around the early 1900s and as late as the 1950s among the Unuit Indians of Northern Canada and the highland dwellers of Papua New Guinea [9].

Accurate statistics on tuberculosis mortality only became available with the advent of the re- 
port of the Registrar General of England and Wales in 1840 [10]. From that time it would seem that the incidence of tuberculosis fell steadily at about $1.7 \%$ per annum for over a century with the exception of the years covering the two World Wars [11].

The risk of being infected with tuberculosis is therefore partly dependent on which year a person was born. Those born in 1920s, eighty years ago, in the UK, would be very much more likely to be infected over their lifetime compared with someone born in the 1980s [12,13].

In Liverpool we conducted a tuberculin skin test survey which showed that a quarter of those over 65 had a positive skin test indicating previous infection compared with none aged under thirty five [14]. A positive skin test was independent of previous BCG. These findings are consistent with the theory that older people are more likely to be infected than younger because they have lived through a time of higher prevalence of disease.

The reasons for this steady decline for over a century are disputed but improved living conditions have certainly played a part and some form of natural selection may also have occurred [15].

If the pandemic theory of tuberculosis spread is correct then tuberculosis peaks were at their highest among the white population of Western Europe earlier than anywhere else, so the decline will have stared in this part of the world $[9,11]$.

Higher rates elsewhere in the world, to some extent, reflect the fact that rates peaked in these areas later so that rates have had less time to fall.

\section{Geographical aspects}

The reason for the wide disparity of rates across the globe seen currently is related to the way tuberculosis has moved across the globe as described in the previous section.

By far the greatest risk factor for infection across the globe is the incidence of tuberculosis in the community in which an individual was born and spent their early years (fig. 1). Individuals born in a part of the world with a very high incidence of disease such as Southern Asia or sub-Saharan Africa will have a very high risk of infection. Annual rates of infection can be calculated from sequential tuberculin skin test surveys or by testing different age groups of children and young people [16]. These have been shown to be especially high in Southern Africa [17].

The incidence of disease in a country of origin is reflected in the incidence of disease in these individuals on immigration to a developed country [18-20].

This can be seen very clearly in rates of disease by ethnic origin in the UK and in the USA [21-22].

Thus those immigrating from China to the UK have rates of disease about 10 times the rate in the indigenous white population (table 1), those from South Asia have rates about 20-30 times the white rate and those from Africa rates 80 times as great.

The sooner disease presents after arrival in the adopted country, the higher the rate of disease appears to be (table 2). Children born to immigrant communities have rates intermediate between those of the same ethnic group born in the country of origin and white children born in the UK.

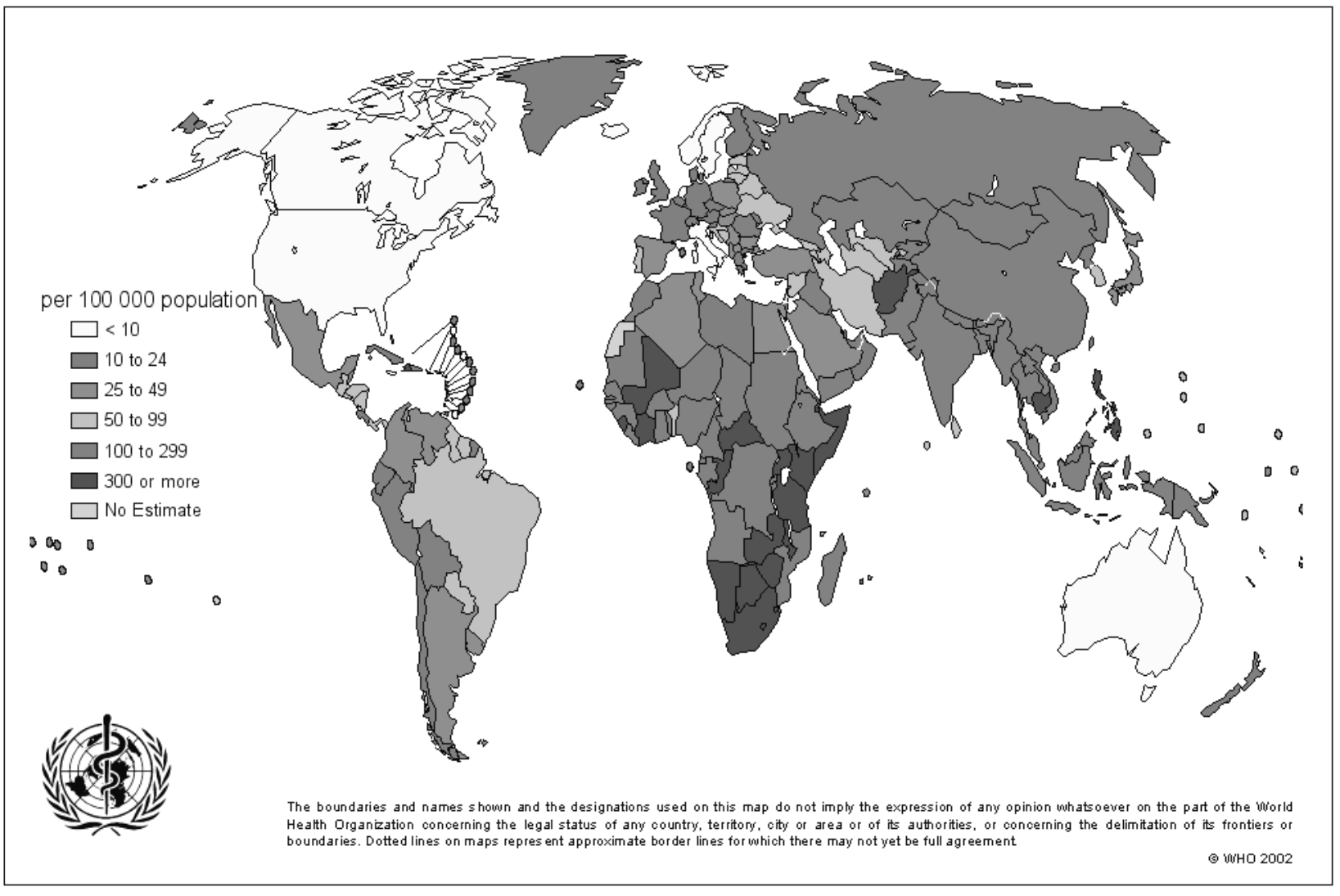

Fig. 1. - Estimated TB Incidence Rates, 2000. 
Table 1. - Annual number of patients with tuberculosis and rate of disease in England and Wales by ethnic group - Reproduced from reference 21 , with permission

\begin{tabular}{|c|c|c|c|c|c|c|c|c|c|}
\hline \multirow[b]{2}{*}{ Ethnic group } & \multicolumn{3}{|l|}{1988} & \multicolumn{3}{|l|}{1993} & \multicolumn{3}{|l|}{1998} \\
\hline & $\mathrm{No}{ }^{\star}$ & Rate $^{\star \star}$ & $95 \% C I$ & $\mathrm{No}{ }^{*}$ & Rate $^{\star *}$ & $95 \% C I$ & $\mathrm{No}^{*}$ & Rate $^{\star \star}$ & $95 \% C I$ \\
\hline Black African $†$ & 77 & 64.4 & 58.1 to 72.2 & 355 & 151 & 140 to 164 & 743 & 210 & 198 to 225 \\
\hline Indian subcontinent & 1784 & 132 & 128 to 136 & 2101 & 128 & 125 to 132 & 2141 & 121 & 118 to 124 \\
\hline Pakistani & 528 & 115 & 109 to 121 & 841 & 155 & 148 to 164 & 826 & 143 & 136 to 150 \\
\hline Indian & 1163 & 144 & 139 to 151 & 1133 & 125 & 120 to 130 & 1160 & 126 & 121 to 131 \\
\hline Bangladeshi & 93 & 104 & 92.3 to 119 & 126 & 65.7 & 60.5 to 71.8 & 155 & 57.3 & 53.4 to 61.7 \\
\hline Chinese & 48 & 36.2 & 32.8 to 40.3 & 41 & 30.7 & 27.8 to 34.2 & 103 & 77.3 & 70.1 to 86.1 \\
\hline Black Caribbean $+\dagger$ & 137 & 29.4 & 27.8 to 31.1 & 104 & 21.6 & 20.5 to 22.9 & 125 & 26.4 & 25.0 to 27.9 \\
\hline Black other $\ddagger$ & - & - & - & 13 & 8.30 & 7.58 to 9.17 & 25 & 23.7 & 21.3 to 26.8 \\
\hline White & 2504 & 5.36 & 5.33 to 5.39 & 2267 & 4.78 & 4.75 to 4.80 & 2108 & 4.38 & 4.36 to 4.40 \\
\hline Other/mixed & 101 & 17.9 & 17.0 to 18.8 & 223 & 42.4 & 40.3 to 44.7 & 336 & 43.0 & 41.3 to 44.9 \\
\hline All & 4659 & 9.383 & 9.334 to 9.433 & 5104 & 10.08 & 10.03 to 10.13 & 5658 & 10.93 & 10.87 to 10.99 \\
\hline
\end{tabular}

$\star$ Numbers were multiplied by scaling factors ( 1.9384 for $1988 ; 1.886$ for 1993) to give annualised figures for comparison.

${ }^{\star \star}$ Rate per 100000 population.

†In 1988 this group was termed "African".

HIn 1988 this group was termed "West Indian and Guyanese".

$¥$ In 1988 this term did not exist.

"In 1988 this group included those described as "Arab"; this term did not exist in 1993 and 1998.

Note: four cases were missing ethnic group information in 1988; none in 1993; 77 cases in 1998.

Source of population data: 1988, 1993 and 1998 Labour Force Surveys.

Conversely areas of the world where tuberculosis has been allowed to decline over more than a century where living conditions have steadily improved and where little or no migration from developing countries has taken place, such as the northern Scandinavian countries have all but eliminated the disease [23].

\section{Natural factors}

\section{Age}

The year in which a person was born, and therefore the age of the person plays a crucial factor in the risk of being infected. Historically there seems to be a distinct pattern of risk of developing disease over a life time which has the shape of an inverted $\mathrm{U}$. With the exception of the infant years risk of tuberculosis is lowest in later childhood but rises rapidly to peak at about age 25-35. Thereafter rates decline progressively. This picture may reflect a combination of increased risk of infection as the individual grows up and becomes independent, moving out of the house and becoming infected in the community [24].

It may also reflect the fact that susceptibility to infection developing into disease is greatest in young adults.

Work from South Africa suggests that rates in children aged $0-5$ is 3.5 times higher than in adults. As it is unlikely that infection is more frequent in very young children than in adults, young children are very much more likely to develop disease from infection than other groups [25]. Mortality is also highest in these groups.

The lifetime risk of developing disease after infection is $43 \%$ in the first year of life, $24 \%$ between 1 and 5 years and $15 \%$ in adolescents compared to immunocompetent adults with a lifetime risk of $5-10 \%[26,27]$.
A more recent study suggests that rates may increase again in older age groups, those over 65 . Thus the "shape" of risk with age changes from and inverted " $U$ " into a capital "N". This may indicate a natural decline in host defence with the ageing process [28].

\section{Gender}

The association of a tuberculosis risk factor with gender is more difficult to quantify. In some societies social stigma may preclude women from attending tuberculosis clinics and so accurate statistics on the incidence of tuberculosis by gender are difficult to calculate.

Historical evidence, from early in the $20^{\text {th }}$ century suggests that women may have higher rates of tuberculosis than men in the young adult age group, 20-30, which may reflect increased susceptibility due to pregnancy [24]. By mid century females maintained higher rates than men did in the younger age groups but men appeared more susceptible in the older age groups. One worker has attributed this to the fact that males took up the smoking habit with World War I, which increased the risk of tuberculosis [29].

Contemporary evidence from the UK suggests that in the older age groups of the white population rates of disease in males exceed that of females by threefold [21]. This difference is not apparent in the Asian of Black African groups (fig. 2).

All evidence points to there being no gender difference in tuberculosis rates in the 1-14 age group. This suggests that if there is a genuine difference between the genders susceptibility it is not apparent until after puberty implying that hormonal differences may play a part.

\section{Ethnicity}

The difference between tuberculosis rates by ethnic group probably reflects the movement of tubercu- 
Table 2. - Number of patients with tuberculosis and rate of disease by place of birth, year of entry to the UK, and ethnic group in England and Wales, 1998 - Reproduced from reference 21, with permission

\begin{tabular}{|c|c|c|c|c|c|c|c|c|c|c|c|c|c|c|c|}
\hline \multirow[b]{2}{*}{ Ethnic group } & \multicolumn{3}{|c|}{ UK born } & \multicolumn{3}{|c|}{ Born abroad (total) } & \multicolumn{3}{|c|}{$\begin{array}{l}\text { Born abroad (recent } \\
\text { entrants) }{ }^{\star}\end{array}$} & \multicolumn{3}{|c|}{$\begin{array}{l}\text { Born abroad (longer } \\
\text { residents)** }\end{array}$} & \multirow{2}{*}{$\begin{array}{l}\text { Born } \\
\text { abroad } \\
\text { (year of } \\
\text { entry } \\
\text { unknown)t }\end{array}$} & \multirow{2}{*}{$\begin{array}{l}\text { Unknown } \\
\text { missing } \\
\text { place of } \\
\text { birth }\end{array}$} & \multirow{2}{*}{ Total } \\
\hline & No & Rateft & $95 \% C I$ & No & Ratef & $95 \% C I$ & No & Ratef & $95 \% C I$ & No & Ratet & $95 \% C I$ & & & \\
\hline White & 1784 & 3.89 & 3.86 to 3.91 & 219 & 9.85 & 9.61 to 10.1 & 55 & 12.6 & 11.9 to 13.4 & 79 & 4.42 & 4.30 to 4.54 & 85 & 105 & 2108 \\
\hline ISC & 373 & 44.8 & 43.0 to 46.7 & 1656 & 5177 & 170 to 184 & 411 & 359 & 323 to 404 & 875 & 106 & 102 to 111 & 370 & 112 & 2141 \\
\hline $\begin{array}{l}\text { Black African } \\
\text { Black }\end{array}$ & 40 & 28.7 & 26.1 to 31.9 & 657 & 308 & 285 to 335 & 277 & 431 & 375 to 505 & 209 & 140 & 128 to 155 & 171 & 46 & 743 \\
\hline Caribbean & 56 & 20.4 & 19.1 to 22.0 & 59 & 20.6 & 19.3 to 22.2 & 2 & 16.3 & 12.2 to 24.7 & 41 & 21.9 & 20.1 to 23.9 & 16 & 10 & 125 \\
\hline $\begin{array}{l}\text { Other } \\
\text { Missing ethnic }\end{array}$ & 55 & 9.50 & 9.1 to 10.0 & 362 & 82.1 & 77.8 to 87.0 & 143 & 114 & 103 to 128 & 131 & 41.5 & 38.9 to 44.5 & 88 & 47 & 464 \\
\hline $\begin{array}{l}\text { group } \\
\text { Total }\end{array}$ & 2308 & 4.83 & 4.81 to 4.86 & $\begin{array}{r}6 \\
2959\end{array}$ & 73.6 & 72.3 to 75.0 & $\begin{array}{r}3 \\
891\end{array}$ & 118 & 114 to 124 & 1335 & 40.9 & 40.0 to 41.7 & $\begin{array}{r}3 \\
733\end{array}$ & $\begin{array}{r}71 \\
391\end{array}$ & $\begin{array}{r}77 \\
5658\end{array}$ \\
\hline
\end{tabular}

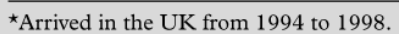

$\star \star$ Arrived in the UK prior to 1994 .

†High numbers of patients born abroad with unknown year of entry for some ethnic groups means that some rates for either recent entry or longer resident categories may be higher than stated.

††Rate per 100000 population.

Source of population data: 1998 Labour Force Survey.

losis as a pandemic across the globe, starting with the industrial revolution and the very high rates this created in Western Europe. As Asia and Africa developed their peaks of high incidence up to 100 years after the white population of Western Europe with less time between the peak incidence and now, what might be termed "baseline" rates are seen to be higher in ethnic groups whose origin is from Africa and Asia [30].

Now of course other factors have come into play which have made rates in many groups of these origins very much higher still, notably poverty in Southern Asia and Africa and HIV/AIDS particularly in Africa but increasingly in South and South East Asia $[4,31,32,33]$. It should be noted that this is not an inherent susceptibility due to race or ethnicity per se but to a combination of many factors which renders people living in certain areas more susceptible than others. It is probably a coincidence that this happens to be reflected most of all in ethnicity.

An example of this may be the comparison between black West Indians and Black Africans. Rates in the latter group are probably at least 20 times higher than the former, though both are inherently of very similar racial and therefore genetic background. Rates in the African group are so much higher because of an "accident" of place of residence [21].

In contrast in a study of people of different ethnic origin living in nursing homes and therefore presumably exposed to a similar risk of infection rates of infection and disease were twice as high in black than in white Americans, presumably indicating reduced natural immunity in the latter group. Within the relatively narrow confines of the same place of residence black individuals appeared to be twice as susceptible to infection as white people though once infected the chance of going on to overt disease was similar in the two groups [34].

\section{Body build}

The association of tuberculosis with body build has been well reviewed. It has been shown that lean underweight tuberculin reactors have a significantly higher risk of developing tuberculosis than persons of, or above, ideal body weight [35, 36, 37].
In a study carried out before World War II it was found that tuberculosis developed very much more frequently in men who were tall and thin than those who were short and heavy set [38]. In a controlled reading of chest $\mathrm{x}$-rays it was shown that those who developed tuberculosis were thinner than those who did not [39].

In a study of 70,000 naval recruits morbidity was four times higher in those who were $15 \%$ or more underweight. Body build was not associated with tuberculin reactivity [40].

In a long term follow up of a BCG trial, reduced subcutaneous fat was associated with increased rates of disease [41].

A study from Norway showed a relative risk of more than 5 fold between the groups with the lowest and highest body mass index. The evidence for a link between tuberculosis and reduced body mass therefore appears to be very strong. To some extent this may compound other evidence of racial or socio-economic differences in risk [42].

\section{Pregnancy}

Accurate quantification of the risk associated with pregnancy is difficult [43]. There is certainly good anecdotal evidence to suggest that becoming pregnant increases a woman's susceptibility to tuberculosis [44]. The marriage of Charlotte Bronte was a matter of concern for her father as he feared that pregnancy could be fatal. As it turned out he was probably justified in these fears.

On the other hand alternative anecdotal evidence favours pregnancy as protective against tuberculosis [45]. A recent review of the data concluded that there was no real objective evidence for or against an association between tuberculosis increase and pregnancy. Provided diagnosis is made and treatment started promptly the outcome for tuberculosis in pregnancy is good [43].

The data does not support the theory that pregnancy is a major risk factor for the development of tuberculosis, though no well designed studies have been conducted. 

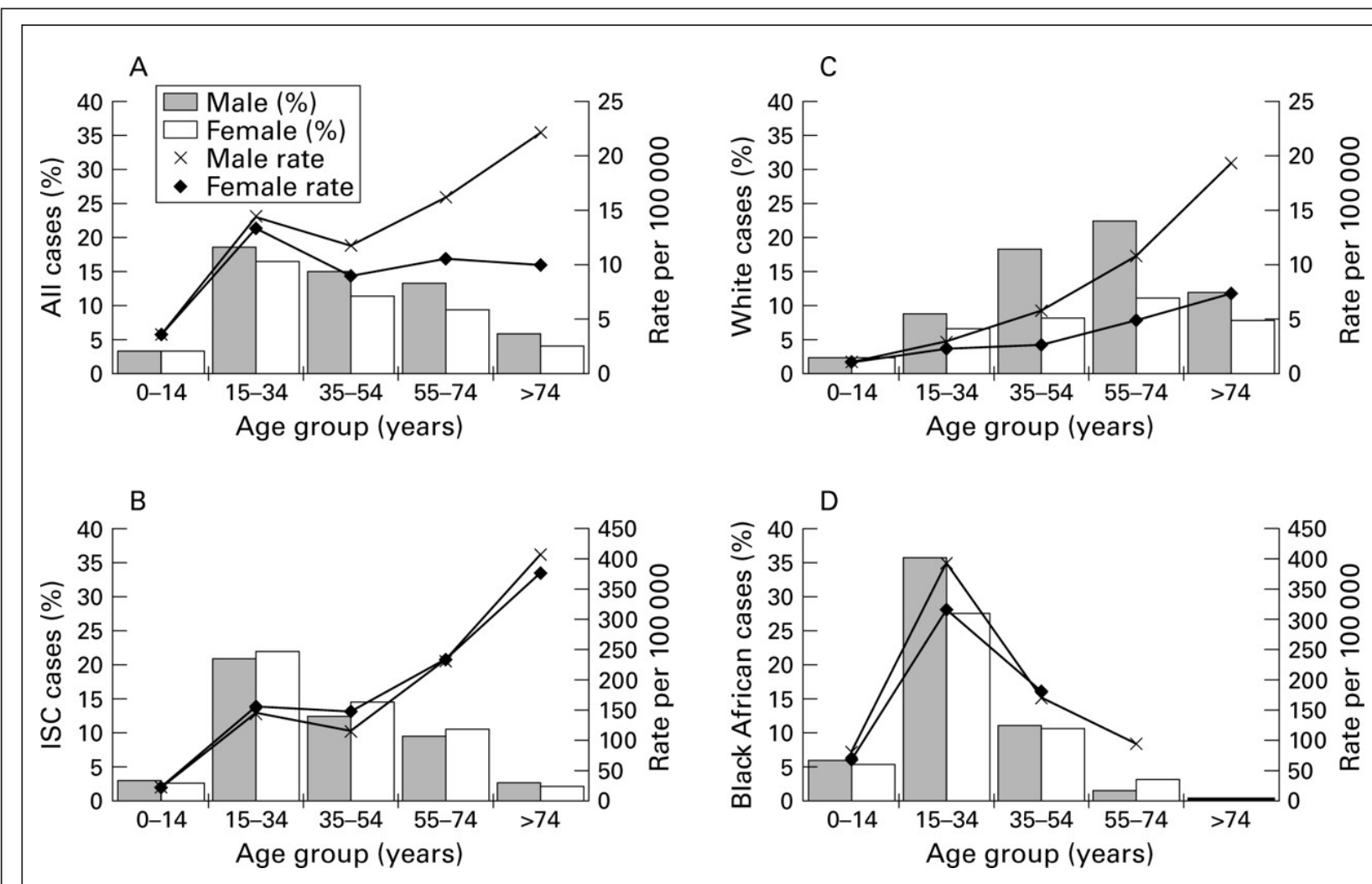

Fig. 2. - Rates and percentages of tuberculosis patients by sex and ethnic origin in England and Wales in 1998 [21]. Reproduced from reference 21, with permission.

There is evidence for a possible deleterious effect on tuberculosis in the puerperium if it is undiagnosed [46].

\section{Life style}

\section{Occupation}

As with most other factors to do with lifestyle, it may be difficult to tease out confounding factors such as ethnicity and poverty when assessing the risk of tuberculosis by occupation. Before the advent of chemotherapy nursing patients with tuberculosis was a well known risk for the disease [47]. With the introduction of specific chemotherapy the risk of acquiring disease by nursing and medical staff decreased considerably but in many studies has still been found to be present [48]. Of particular risk are mortuary technicians.

Miners and other workers in stone have increased risk through silicosis of the lung. (see below).

\section{Poverty}

That there is a very strong correlation between poverty and tuberculosis is not in doubt. Recent studies from the UK have shown a close correlation even in a Western city at the end of the $20^{\text {th }}$ century [49]. What is less clear is the various aspects of poverty which may constitute the increased risk. It is likely that poor housing in terms of crowding leading to increased transmission and poor nutrition leading to diminished immunity are the two most important factors.
Within in the UK at least one paper has made the error of attributing the rise in tuberculosis to poverty because the rise was seen only in the poorest percentile areas of the country [50]. In fact this rise was probably due to the fact that recent migrants to the UK who had high risk because of their ethnicity, tended to move to the poorest areas.

Two separate studies has shown that ethnicity is more important than poverty as a risk factor in these areas [51, 52].

Within the socio-economically deprived population other factors may play a part. Residents in common lodging houses show increased rates [5356]. Those who are homeless on the streets of London are at increased risk. Drug and alcohol abuse increase risk [57].

\section{Diet}

It is often difficult to control for factors related to poverty in order to study just one. A study of life-style factors of over 100 patients in Liverpool and over twice as many controls showed that controls tended to eat more salads and dairy products than patients [58]. It was also of interest that being on treatment for blood pressure seemed to be protective against tuberculosis. Body build was not assessed in this particular study but the tendency for raised blood pressure to be associated with obesity may have a compounding effect on relative protection from tuberculosis. 


\section{Smoking}

The association between smoking and tuberculosis has been established for at least a decade. Original observations suggested that the change in the pattern of tuberculosis between men and women was due to the fact that men took up smoking after the First World War in large numbers whereas women did not [29].

More accurate studies by Doll and the life-style survey in Liverpool showed that those who smoked more than 20 cigarettes a day were between two and three times more likely to develop tuberculosis compared with never smokers $[58,59]$.

The same observation has been made in China and India [60-63]. Here tuberculosis has been shown to be the commonest cause of death in smokers: not an association we normally make in the developed world.

\section{Drinking alcohol}

Drinking is perhaps the most difficult of all factors associated with poverty to quantify risk for. This may be due to reluctance of patients to admit fully their alcohol consumption pattern and the presence of other factors, closely associated with alcohol abuse such as homelessness and smoking.

Poor nutrition and alcoholism go together to impair immunity. Evidence for the strict association between excessive alcohol consumption alone and tuberculosis is limited $[64,65]$.

\section{Drug abuse}

Apart from alcohol there is good evidence that misuse of other drugs particularly by intravenous drug users is associated with increased risk of tuberculosis. Again it can be hard to factor out other confounding variables [66].

\section{Place of residence}

As with other features related to poverty, place of residence may be inextricably linked with confounding variables.

In the 1980s work by Stead in the USA suggested that residents of homes for the elderly may be at increased risk [69]. It was suggested that with the declining immunity of old age and the close association of such individuals within residential homes, an increased risk was emerging. Though Stead was able to show this in his place of work in Little Rock Arkansas, other studies in the USA, UK and Hong Kong showed no such association $[68,69,70]$. Only in the study or residential homes for the elderly in Hong Kong was it shown that residents who had communal meals together were at increased risk [69].

\section{Sunlight exposure}

Sunlight exposure and Vitamin D supplementation were used as treatment for tuberculosis from the middle of the nineteenth century until specific chemother- apy became available. Recent work on the immunological mechanisms for Vitamin D, which have shown that the vitamin is important in macrophage activation, give credence to these methods [71].

It has been suggested that the lack of sunlight in the UK and other temperate areas is partly responsible for the high rates of tuberculosis, particularly non-respiratory tuberculosis found in migrants to the UK from South Asia [72].

The hypothesis is that these individuals acquire infection in their country of origin where sunlight is plentiful and Vitamin D levels high. Infection is therefore contained.

On moving to a country where sunlight is scarce, D levels fall and the previous efficient immune system in compromised. So active disease erupts. The parallel has been made to HIV infection acquired after tuberculosis infection also causing disease to erupt [73].

\section{Specific protection}

\section{$B C G$}

The science of BCG, the vaccine against tuberculosis, is fraught with controversy.

Studies carried out by the British Medical Research Council in the 1950s showed that BCG, when given to teenage school children gave about $75 \%$ protection for 15 years [74]. Since 1953 it has been national policy, in the UK, to vaccinate all children aged 12-13. Thus in theory the entire population receives some protection from early teenage years through to about the age of 30 . The reason for choosing that age range was because in the 1950s cases rates were highest in young adults. The limited length of time for which BCG appeared to be protective would therefore be maximal at the age when most people suffered from the disease. Secondly the form of tuberculosis which pre-teenage children suffer from (primary) is not usually infectious, whereas the form suffered by adults is frequently infectious. Providing protection during early adult life would therefore reduced transmission.

In addition to the national policy for all teenagers, BCG is given at birth to those at high risk of disease; those with a family history of tuberculosis and those from minority ethnic groups.

Because of variation in trial results, most countries give $\mathrm{BCG}$ at birth to provide protection in the early years when infection can often lead to devastating widespread disease such as miliary tuberculosis or tuberculous meningitis. This is particularly important in high prevalence countries where the chance of being infected in very early life is high. Some countries such as the USA have chosen not to use it because most trials there have not shown any protective effect [75].

In 1994 a "metanalysis" of all the trials was published [76]. This looked at a total of 1264 articles, 70 in depth, 14 prospective trials and 12 casecontrol studies. The authors found that seven trials show a protective effect from death of $71 \%$, five trials showed protection from meningitis of $64 \%$, three, protection from disseminated disease of 
$78 \%$ and three, protection from laboratory-confirmed disease of $83 \%$.

The authors concluded that geographical site of study explained $66 \%$ of variability.

They also found that on average BCG reduces risk of infection leading to disease by $50 \%$.

This is probably an erroneous conclusion, as the efficacy of BCG cannot be averaged. Trials show it to be $80 \%$ protective in one place and $20 \%$ in another. Average efficacy should not be taken.

In terms of risk for tuberculosis it may be concluded that infants and teenagers, in the UK, who have had BCG, are probably at reduced risk of developing tuberculosis by about $75 \%$ for no more than fifteen years [75].

BCG does relatively little to reduce risk of tuberculosis across populations of all ages.

\section{Medical factors}

\section{HIVIAIDS}

Since it was first described it was apparent that HIV infection, by impairing cell mediated immunity, incurred a unique susceptibility on the patient to acquire tuberculosis (table 3). The epidemiology of tuberculosis has been completely altered in areas where HIV infection is prevalent, particularly in areas where tuberculosis was already endemic such as sub-Saharan Africa. One of the earliest studies to quantify the risk, carried out on intravenous drug addicts in New York showed that HIV-infected tuberculin positive individuals carried an annual risk of reactivation of $7.9 \%$ This estimates HIV infection to increase the risk of infection progressing to disease by approximately a hundred fold [77] .

Cohort studies in African countries have shown that the annual risk of developing active tuberculosis in co-infected persons range from $5 \%$ to $15 \%$, compared with a $0.2 \%$ annual risk form those not HIV infected [31].

Two studies from the USA, using techniques of molecular epidemiology, have shown that twothird of tuberculosis in HIV positive individuals was due to recent person-to-person transmission rather than reactivation of latent disease. In HIV infection recent infection rapidly leads on to disease $[78,79]$.

The strong association of tuberculosis with HIV in Africa has lead to the upsurge of tuberculosis in that region. Case numbers in Tanzania and Malawi increased by 5 to 6 fold between 1985 and 2000 [31].

In contrast there is evidence that patients with HIV seropositive tuberculosis are likely to be less infectious than HIV seronegative patients [80, 81]. This is probably because the type IV hypersensitivity response is reduced in HIV seropositivity reducing the likelihood of cavitation with concomitant high bacterial count in the sputum.

\section{Silicosis}

In addition to HIV infection other medical conditions increase the risk of infection leading to dis- ease. Silicosis acquired as a result of working in mines or with stone has a relative risk of about 30 fold [82].

\section{Immunosupressive treatment}

Immunosupressive treatment will increase risk by suppressing the cell mediated immune response to infection with M. tuberculosis. Patients exposed to tuberculosis undergoing immunosuppression have very specific requirements for preventive therapy. In countries with high rates of tuberculosis, this is the commonest complication of renal transplant [83].

There has been recent interest in the new TNFalpha blocking drugs used in the treatment of rheumatoid arthritis. These apparently increase the risk of tuberculosis infection developing into disease by approximately five fold [84].

\section{Haemodialysis}

Patients undergoing haemodialysis and those with chronic renal failure run an increased risk of 10 to 15 fold.

\section{Gastrectomy and Jejunoileal bypass}

Having had a gastrectomy or jejunoileal bypass increases the risk of tuberculosis by five and 30 to 60 fold respectively. The mechanism as to why this should be is not clear but may be related to nutritional deficiency.

\section{Carcinoma}

Cancer patients with head and neck tumours, malignant lymphomas, lung cancer, lymphosarcoma and reticulum cell sarcoma have up to a 16 fold increased risk.

\begin{tabular}{|c|c|c|}
\hline & $\begin{array}{l}\text { Absolute/1,000 } \\
\text { Person-years }\end{array}$ & Relative risk \\
\hline Infection $>7$ years past & 0.7 & \\
\hline Infection <1 year past & 10.4 & \\
\hline HIV infection & 79 & \\
\hline AIDS & & 170.3 \\
\hline Fibrotic lesion & $2.0-13.6$ & \\
\hline Silicosis & & 30 \\
\hline Immunosupressive & & 11.9 \\
\hline \multicolumn{3}{|l|}{ Treatment } \\
\hline Haemodialysis & & $10-15$ \\
\hline Gastrectomy & & 5 \\
\hline Jejunoileal bypass & & $27-63$ \\
\hline Carcinoma of head or neck & & 16 \\
\hline Diabetes & & $2.0-3.6$ \\
\hline
\end{tabular}


Table 4. - Factors involved in susceptibility or resistance to tuberculosis and subject to genetically determined variation.

Factor or gene

Natural resistance-associated macrophage protein (NRAMP 1)

Mannose binding lectin protein

HLA-D

Vitamin D

Locus on chromosome 15

Locus on X chromosome

Haptoglobin

$\mathrm{Km} 1$ immunoglobulin allotypes

Various cytokines
Function or mode of action

? Regulation of Phagosome cation levels.

Entry of mycobacteria into cells.

Antigen presentation.

Macrophage activation.

Unknown.

Unknown. May account for higher rates of tuberculosis in males.

? Regulator of lymphocyte function.

? Related to autoimmune tissue damage.

T cell maturation and patterns of immune reactivity.

\section{Diabetes}

Diabetes in known to render the patient more susceptible to any infection. Tuberculosis has a 24 fold increase in these patients.

\section{Genetic Factors}

There have been many claims that populations and racial groups vary in their resistance to tuberculosis but it has been very difficult to separate the genetically determined factors from environmental ones. Nevertheless, several studies on monozygotic and dizygotic twins clearly indicate that inheritable factors are involved in determining susceptibility and resistance to overt tuberculosis after infection [85]. The human immune response to tuberculosis is multi-factorial, involving the uptake of tubercle bacilli by macrophages, class II HLA determined antigen presentation, activation of macrophages by $\mathrm{T}$ cell-derived cytokines and vitamin D [86, 87], granuloma formation and apoptosis of bacteria-laden cells. These processes are genetically controlled and several of the genes involved have been identified. Although much interest focused on the HLA genes, notably the HLA-DR2 and HLA-DQB1 loci, that determine which mycobacterial antigens are presented to the helper $\mathrm{T}$ cells $[88,89]$ interest has now largely shifted to non-HLA genes. Of these, two are of particular interest, the genes coding for the vitamin D receptor [86], and the natural resistance-associated macrophage protein (NRAMP1) gene [90]. The latter is the human equivalent of a gene found to determine resistance to intracellular parasites, such as Leishmania and Salmonella, in the mouse and it clearly affects human resistance to tuberculosis. Its function is unknown but there is evidence that it regulates the concentration of iron and perhaps other cations in the phagosomes of the macrophage.

Other genes affecting immune function have also been associated with resistance to tuberculosis [91]. These include genes determining the allotypes of the Km1 light chain immunoglobulin allotype [92], and of haptoglobin [93, 94], but it is not clear whether these are of prime importance or merely reflect gene linkage. Other genes currently under investigation include those affecting vitamin $\mathrm{D}$ levels (see below), the mannose binding lectin protein [95], and the various cytokines involved in protective immunity [96].

Although there have been a few examples of susceptibility to tuberculosis and other mycobacterial diseases within families associated with specific defects in gamma-interferon and other cytokines, family-based linkage studies and population-based case-control studies clearly indicate that resistance to tuberculosis is generally the result of a large number of genes inherited in a complex way [91]. The factors involved in susceptibility and resistance to tuberculosis that have been shown to very according to genotype are summarised in table 4.

\section{Conclusions}

Susceptibility to tuberculosis is multifactorial and complex. A better understanding of these will help to target screening of disease and allow preventive therapy to be given only to those at particular risk. This will help to harness resources to where they are most needed and prevent waste both in terms of reduced morbidity and mortality and in material.

Acknowledgements: The author would like to thank the BMJ publishing group for permission to publish figs. 2 and tables 1 and 2 .

Also Professor John Grange for permission to use the section on Genetics.

\section{References}

1. American Thoracic Society Centers for Disease Control and Prevention: Targeted Tuberculin Testing and Treatment of Latent Tuberculosis Infection. Am J Resp Crit Care Med 2000; 161: S221-S247.

2. Mazurek et al. Comparison of a whole-blood interferon-y assay with tuberculin skin testing for detecting latent $\mathrm{M}$. tuberculosis infection. JAMA 2001; 286 (14): 1740.

3. Joint Tuberculosis Committee of the British Thoracic Society. Chemotherapy and management of tuberculosis in the United Kingdom: recommendations 1998. Thorax 1998; 53: 536-548.

4. Dye C. Epidemilogy in Clinical Tuberculosis 3rd editn: Edit: PDO Davies, Arnold, London 2003. pp 21-42. 
5. Canci A, Minozzi S, Borgognini Tarli S. 1996 New evidence of tuberculous spondylitis from Neolithic Liguria (Italy). International J Osteoarchaeology 6: 497-501.

6. Pesanti EL. 1995 A short history of tuberculosis. In L. I. Lutwick (ed): Tuberculosis. London, Chapman and Hall Medical, pp 5-19.

7. Howe GM. 1997 People, environment, disease and death. A medical geography of Britain through the ages. Cardiff, University of Wales Press.

8. Davies PDO. Tuberculosis and migration. J Roy Coll Phys Lond 1995; 29: 113-118.

9. Grzybowski S, Enarson D. Tuberculosis, in Current Pulmonology (edit: DH Simmons Year Book Medical Publishers, Chicago, pp 75-96.

10. Registrar General's weekly returns (1840). HMSO, London 1840.

11. Davies RPO, Tocque K, Bellis M, Remmington T, Davies PDO. Historical declines in tuberculosis in England and Wales; social conditions or natural selection? Versalius 1999; V: 25-29. Also published as unresolved issues in Int J Tuberc Lung Dis 1999; 12: 1051-1054.

12. Springett VH. An interpretation of statistical trendsin tuberculosis. Lancet 1952; I: 521-25.

13. Springett VH. An interpretation of statistical trendsin tuberculosis. Lancet 1952; I: 575-80.

14. Syed Q, Bellis MA, Beeching NJ et al. Tuberculin testing in two Liverpool Social Clubs: The effects of tuberculosis outbreak on background positivity. Thorax 1996; 51: 624-627.

15. D'Arcy Hart P, Payling Wright G. Tuberculosis and social conditions in England with special reference to young adults. London: National Association for the Prevention of Tuberculosis, 1939.

16. Bleiker MA, Greip WA, Beunders BJW. The decreasing tuberculin index in Dutch recruits. KNCV, The Hague The Netherlands, Selected papers 1964; 8: 38-49.

17. Mwinga AG. Specific problems of control in Africa. In: Clinical Tuberculosis, Edit PDO Davies, Arnold London 2003. pp 417-426.

18. Stevenson DK. Tuberculosis in Pakistanis in Bradford. Brit Med J 1962; I: 1382-6.

19. Enarson D, Ashley MJ, Grzybowski S. Tuberculosis in Immigrants to Canada. Am Rev Respir Dis 1979; 119: 11-18.

20. Enarson D, Sjogren I, Grzybowski S. Incidence of tuberculosi among Scadanavian immigrants to Canada. Europ J Respir Dis 1980; 61: 139-42.

21. Rose AMC, Watson JM, Graham C et al. Tuberculosis at the end of the 20th century in England and Wales: results of a national survey in 1998. Thorax 2001; 56: 173-179.

22. Small PM, Fujiwara PI. Management of tuberculosis in the United States. N Engl J Med 2001; 345: 189-200.

23. Broekmans JF, Migliori GB, Rieder HL et al. European framework for tuberculosis control and elimination in countries with a low-incidence. Eur Respir J 2002; 19: 765-775.

24. Springett VH. A comparative study of tuberculosis mortality rates. Journal of Hygiene 1950; 48: 361-95.

25. van Rie A, Beyers N, Gie RP, Kunneke M, Zietsman L, Donald PR. Childhood tuberculosis in an urban population in South Africa: burden and risk factor. Arch Dis Child 1999; 80: 433-437.

26. Miller FJW, Seale RME, Taylor MD. Chapter 4. In: Tuberculosisin children: evolution, control, treatment. Churchill, London: 1963; 73.

27. Schaaf HS, Gie RP, Beyers N. Tuberculosis in Childhoos. In: Clinical Tuberculosis: edit: PDO Davies Chapter 9. Arnold: London 2003: 154

28. Tocque K, Bellis MA, Tam CM et al. Long-term trends in tuberculosis: comparison of age-cohort data in Hong Kong and England and Wales. Am J Resp Crit Care Med 1998; 158: 484-488.

29. Lowe CR. An association between smoking and respiratory tuberculosis Brit Med J 1956; II: 1081-1086.
30. http://www.hpa.org.uk/infections/topics_az/tb/menu.htm

31. Harries AD. The association between HIV and tuberculosis in the developing world with a special focus on subSaharan Africa. In: Clinical Tuberculosis, PDO Davies Ed., Arnold London 2003. pp 417-426.

32. Banavaliker JN. Control in high prevalence countries. In Clinical Tuberculosis, PDO Davies Ed., Arnold London 2003. pp 417-426.

33. Udwadia ZF. Specific problems of control in India. In Clinical Tuberculosis, PDO Davies Ed., Arnold London 2003. pp 417-426.

34. Stead WW, Senner JW, Reddick WT, Lofgren JP. Racia differences in susceptibility to infection by Mycobacterium tuberculosis. New Eng J Med 1990; 322: 422-427.

35. Sneider DE. Tuberculosis and body build. Sama 1987; 22: 3299 (only).

36. Comstock GW. Prevention of tuberculosisamong tuberculin reactors: maximising benefits, minimising risks. JAMA 1986; 256: 2729-2730.

37. Reed LJ, Love AG. Biometric studies in US army officers: somatological norms in disease. Hum Biol 1933; 5: 61-93.

38. Long ER, Jablon S. Tuberculosis in the Army of the united States in World Warv II: an epidemiological study with an evaluation of X-ray screening, medical Monograph series. Washington, DC, Veterans administration, 1955.

39. Berry WTC, Nash FA. Studies in the aetiology of pulmonary tuberculosis. Tubercle 1955; 36: 164-174

40. Palmer CE, Jablon S, Edwards PQ. Tuberculosis morbidity of youn men in relation to tuberculin sensitivity and body build. Am Rev Tuberc Pulm Dis 1957; 56: 517-539.

41. Comstock GW, Palmer CE. Long-term results of BCG vaccination in the Southern United States. Am Rev Respir Dis 1966; 93: 171-183.

42. Tverdal A. Body mass index and incidence of tuberculosis. Europ J Respir Dis 1986; 69: 255-362.

43. Snider D. Pregnancy and tuberculosis. Chest 1984; 86: 10S-13S.

44. Hevdall E. Pregnancy and tuberculosis. Acta Med Scand 1953; 147 (suppl 286): 1-101.

45. Giercke HW. Tuberkuloseablaufe kurz nach Schwangerschaftsbeenigung. Z Tuberk 1956; 108: 1-8.

46. Omerod LP. Tuberculosis in pregnancy and the puerperium. Thorax 2001; 56: 494-499.

47. Tuberculosis in young adults: report on the Prophit Tuberculosis. Survey, 1935-1944; by M. Daniels, Royal College of Physicians of London Prophit Committee. London, 1948.

48. Meredith S. Watson JM. Citron KM. Cockcroft A. Darbyshire JH. Are healthcare workers in England and Wales at increased risk of tuberculosis? Brit Med J 1996; 313: 522-5.

49. Spence DPS, Hotchkiss J, Williams CSD. Tuberculosis and Poverty. PDO Davies. Brit Med J 1993; 307: 759761.

50. Bhatti N, Law MR, Morris JK, Halliday R, Moore-Gillon JC. Increased incidence of tuberculosis in England and Wales: a study of the likely causes. Brit Med J 1995; 310: 967-969.

51. Tocque K, Doherty M, Bellis M, Spence PDS, Jamieson ID, Davies PDO. Tuberculosis Notifications in England: The Relative effects of poverty and ethnicity. International Journal of Tuberculosis and Lung Disease 1998; 2: 213-8.

52. Hawker JI, Bakhshi SS, Ali A, Farrington P. Ecological analysis of ethnic differences in relation between tuberculosis and poverty. Brit Med J 1999; 319: 1031-1034.

53. Patel KR. Pulmonary tuberculosis in residents in lodging houses, night shelters and common hostels in Glasgow: a 5 year prospective survey. Br J Dis Chest 1985; 79: 60-66. 54. Capewell S France AJ, Anderson M, Leitch AG. The di- 
agnosis and management of tuberculosis in common hostel dwellers. Tubercle 1986; 67: 125-31.

55. Nolan CM, Elarth AM, Barr H et al. An outbreak of tuberculosis in a shelter for homeless men. Am Rev Respir Dis 1991; 143: 257-61.

56. Zolopa AR, Hahn JA, Gorter R et al. HIV and tuberculous infection in San Francisco's homeless adults. JAMA 1994; 272: 455-61.

57. Kumar D, Citron KM, Leese J, Watson JM. Tuberculosisamong the homeless at a temporary shelter in London: report of a chest x-ray screening programme. J Epiemiol Community Health 1995; 49: 629-33.

58. Tocque K, Bellis MA, Beeching N, Sayed Q, Remmington T, Davies PDO. A case-control study of lifestyle risk factors associated with tuberculosis in the city of Liverpool, Northwest England. Eur Resp J 2001; 18: 959-964.

59. Doll R, Peto R. Mortality in relation to smoking: 40 years' observations on male British doctors. Brit Med J 1994; 309: 901-999.

60. Yu GP, Hsieh CC, Peng J. Risk factors associated with the prevalence of pulmonary tuberculosis among sanitary workers in Shanghai. Tubercle 1988; 69: 105-12.

61. Dong B, Ge N, Zhou Y. Smoking and alcohol consumption as risk factors of pulmonary tuberculosis in Chengdu: a matched case-control study. Hua Xi Yi Ke Da Xue Xue Bao 2001; 32: 104-6.

62. Gajalakshmi V, Prto R, Kanaka TS, Jha P. Smoking and mortality from tuberculosis and other diseases in India: retrospective study of 43000 adult male deaths and 35000 controls. Lancet 2003; 362: 507-15

63. Gupta PC, Mehta HC. Cohort Study of all cause mortality among tobacco users in Mumbai, India. Bull World Health Organ 2000; 78 (7): 877-83.

64. Bajker RC, Jerrels TR. Recent developments in alcoholism: immunilogical aspects. Rec Dev Alcohol 1993; 11: 249-71.

65. Watson RR, Borgs $\mathrm{P}$, Witte $\mathrm{M}$ et al. Alcohol, immunomodulation and disease. Alcohol Alcoholism 1994; 29: 131-9.

66. Anonymous. Crack cocaine use among persons with tuberculosis - Contra Costa County, California, 1987-1990. MMWR - Morbidity \& Mortality Weekly Report 1991; 40: 485-9.

67. Stead WW, Lofgren JP, Warren E, Thomas C. Tuberculosis as an endemic and nosocomial infection among the elderly in nursing homes. N Eng J Med 1985; 312: 1483-7.

68. Perez-Stable EJ, Flaherty D, Schecter G, Slutkin G, Hopewell PC. Conversion and reversion of tuberculin reactions in nursing home residents. Am Rev Respir Dis 1988; 137: 801-4.

69. Nisar M, Williams CSD, Ashby D, Davies PDO. Tuberculin screening of residential homes for the elderly. Tho$\operatorname{rax} 1993$; 48: 1257-60.

70. Woo J, Chan HS, Haslett CB et al. Tuberculosis among elderly Chinese in residential homes: Tubercuin reactivity and estimated prevelance. Gerontology 1996; 42: 155-162.

71. Denis M. Killing of Mycobacterium tuberculosis with human monocytes: activation by cytokines and calcitriol. Clin Exp Immunol 1991; 84: 200-6.

72. Rook GA, Steele J, Fraher L et al. Vitamin D3, gamma interferon and control of proliferation of Mycobacterium tuberculosis by human monocytes. Immunology 1986; 57: 159-63.

73. Davies PDO. A possible link between vitamin D deficiency and impaired host defence to Mycobacterium tuberculosis. Tubercle 1985; 66: 301-6.

74. Hart PD. Efficacy and applicability of mass BCG vaccination in tuberculosis control. Brit Med J 19677; 1: 587592.

75. Rieder HL. BCG vaccination. in Clinical Tuberculosis $3^{\text {rd }}$ editn, PDO Davies Ed., Arnold, London 2003. pp 21-42.

76. Colditz GA et al. Efficacy of BCG Vaccine in the pre- vention of Tuberculosis. JAMA 1994; 271: 698-702. Newborns and infants. Paediatrics 1995; 96: 29-35.

77. Selwyn PA, Hartel D, Lewis VA et al. A prospective study of the risk of tuberculosis among intravenous drug users with human immunodeficiency virus infection. $N$ Eng J Med 1989; 320: 545-550.

78. Small PM, Hopewell PC, Singh SP. The epidemiology of Tuberculosis in San Francisco. A population-based study using conventional and molecular methods. $N$ Eng J Med 1994; 330: 1703-1708.

79. Alland D, Kalkut GE, Moss AR et al. Transmission of tuberculosis in New York city. $N$ Eng J Med 1994; 330: 1710-1716.

80. Carvalho AC, De Riemer K, Nunes ZB et al. Transmission of Mycobacterium tuberculosis patients. Am J Respir Crit Care Med 2001; 164: 2166-71.

81. Cruciani M, Malena M, Bosco O, Gatti G, Serpellani G. The impact of human immunodeficiency virus type 1 on infectiousness of tuberculosis: a meta-analysis. Clin Infect Dis 2001; 33: 1922-30.

82. Rieder HL, Cauthen GW, Comstock GW, Snider DE. Epidemiology of tuberculosis in the United States. Epid Rev 1989; 11: 79-98.

83. Naqvi A, Rizvi A, Hussain Z et al. Developing world perspective of posttransplant tuberculosis: morbidity, mortality, and cost implications. Transplantation Proceedings 2001; 33: 1787-8.

84. Keane J, Gershon S, Wise RP et al. Tuberculosis associated with infliximab, a tumor necrosis factor-alpha neutralizing agent. $N$ Eng J Med 2001; 345: 1098-1104.

85. Comstock GW. Tuberculosis in twins: a re-analysis of the Prophit survey. Amer Rev Respir Dis 1978; 117: 621-4.

86. Bellamy R, Ruwende C, Corrah T et al. Tuberculosis and chronic hepatitis B virus infection in Africans and variation in the vitamin D receptor gene. J Infect Dis 1999 179: 721-4.

87. Wilkinson RJ, Llewelym M, Toossi Z et al. Influence of vitamin $\mathrm{D}$ deficiency and vitamin $\mathrm{D}$ receptor polymorphisms on tuberculosis among Gujarati Asians in west London: a case-control study. Lancet 2000; 355: 618-21.

88. Bothamley GH, Beck JS, Schreuder GM et al. Association of tuberculosis and M. tuberculosis-specific antibody levels with HLA. J Infect Dis 1989; 159: 549-55.

89. Goldfeld AE, Delgado JC, Thim S et al. Association of an HLA-DQ allele with clinical tuberculosis. Jama 1998; 279: 226-8.

90. Bellamy R, Ruwende CR, Corrah T, McAda KPWJ, Whittle HC, Hill AVS. Variations in the NRAMP-1 gene and susceptibility to tuberculosis in West Africans. N Engl J Med 1998; 338: 640-4.

91. Bellamy R, Beyers N, McAdam KP et al. Genetic susceptibility to tuberculosis in Africans: a genome-wide scan. Proc Natl Acad Sci USA 2000; 97: 8005-9.

92. Gibson JA, Grange JM, Beck JS, Kardjito T. An association between $\mathrm{Km} 1$ immunoglobulin allotype and pulmonary tuberculosis in Indonesia. Exp Clin Immunogenet 1987; 4: 129-35.

93. Shenderova RJ, Osina NA. Syvorotochenye sistemy krovi u bol'nykh tuberkulezom [The blood serum systems in patients with tuberculosis]. Probl Tuberk 1991; 3: 54-6 (In Russian - English summary).

94. Grange JM, Kardjito T, Beck JS, Ebeid O, Kohler W, Prokop O. Haptoglobin: an immunoregulatory role in tuberculosis? Tubercle 1985; 66: 41-7.

95. Salvaraj P, Narayanan PR, Reetha AM. Association of functional mutant homozygotes of the mannose binding protein gene with susceptibility to pulmonary tuberculosis. Tuber Lung Dis 1999; 79: 221-7.

96. Bellamy R, Ruwende C, Corrah T, McAdam KP, Whittle $\mathrm{HC}$, Hill AV. Assessment of the interleukin 1 gene cluster and other candidate gene polymorphisms in host susceptibility to tuberculosis. Tuber Lung Dis 1998; 79: 83-9. 